\title{
EDITORIAL
}

\section{Células tronco embrionárias: back to 7o's}

A discussão moral e ética acerca dos transplantes de órgãos na década de 70 do século XX está de volta. As considerações sobre "usar uma vida" para salvar outra versus a possibilidade terapêutica revolucionária, se repetem na discussão sobre a utilização das células tronco embrionárias. Neste cenário, é importante ressaltar que hoje o Brasil tem tecnologia intelectual e física para ser um grande centro mundial no desenvolvimento de pesquisa nesta área. Apesar disso, a população desinteressada e desorganizada, movida pela latinidade e o profundo viés religioso, permite que a discussão, ética e moral, permaneça elitizada, e a informação seja restrita e restritiva. Em algum momento foi esclarecido à população que a massa celular interna de um blastocisto é apenas um conjunto de 64 a 100 células aglomeradas? E que estas não se tratam de um bebê com estrutura corporal, fisionomia e personalidade, mas sim de um pré-embrião? E que este jamais terá um útero para sua gestação? E que clonagem terapêutica não possibilita gerar cópias de indivíduos (reprodutiva), mas sim de células, tecidos ou órgãos? Desde a década de 80, a Inglaterra começou a discussão para definir sua legislação sobre o tema. No decorrer dos anos, lá foi permitida a utilização de células embrionárias, prevendo que até o $14^{\circ}$ dia, ou seja, antes do surgimento do sistema nervoso primitivo, não se tem um embrião e sim um pré-embrião, que pode ser manipulado. Apesar dos esforços de poucos, que muito lutaram por esta conquista, no Brasil, a Lei de Biossegurança de 2005, representa um avanço cerceado, condizente com as tímidas iniciativas de fomento e desenvolvimento de pesquisa nesta área, geradas de lá para cá, mais incisivamente no ano de 2008. Neste período, há que se ressaltar o papel da mídia em noticiar com destaque cada conquista, seja na utilização de células tronco adultas, cordão umbilical ou embrionárias. Apesar do reconhecimento do pequeno, mas excelente trabalho que aqui vem sendo feito, aparentemente bem recebido pela população, o alarde muitas vezes não esclarece que os testes ou tentativas terapêuticas ainda têm passos, mesmo que largos, a percorrer até a obtenção de terapias bem estabelecidas, bem controladas, aprovadas e acessíveis à população. Ao invés de temer nomes como: clonagem terapêutica, terapia gênica, células tronco embrionárias, como entidades que violam a integridade e os valores humanos, a população deveria estar alerta e ativa, tendo como experiência a realidade bem estabelecida e moralmente aceita, que beneficia milhões de pessoas: a dos transplantes de órgãos.

\section{Bartira De Aguiar Roza}

Doutora em Enfermagem pela Universidade Federal de São Paulo. Membro da Câmara Técnica Nacional de Doação de Órgãos do Sistema Nacional de Transplantes/MS. Coordenadora do Departamento de Enfermagem da Associação Brasileira de Transplante de Órgãos (ABTO). Enfermeira Máster do Hospital Albert Einstein - HIAE, São Paulo (SP), Brasil.

\author{
João Carlos da Silva Bizario \\ Diretor Cientifico do Centro de Pesquisas em Distrofia Muscular - AADM/UNAERP. Prof. Titular da Faculdade \\ de Medicina da Universidade Cidade de São Paulo - UNICID, São Paulo (SP), Brasil.
}

